\title{
“E NA HISTÓRIA DE HOJE...": UMA ANÁLISE DO PROCESSAMENTO INFERENCIAL EM POSTAGENS DO FACEBOOK ${ }^{1}$
}

\section{"And in today's story...": analysis of the inferential processing on Facebook posts}

\author{
Júlio Araújo* \\ Sayonara Melo Costa** \\ Márcia Ananda Soares Siqueira de Sousa ${ }^{* * *}$
}

\begin{abstract}
RESUMO
O presente trabalho objetiva analisar como o processamento inferencial é convocado para a (re)construção de sentidos nas postagens da fanpage Conselhos do He-Man, do site de redes sociais Facebook. Para tanto, pautamo-nos nas reflexões de Ducrot $(1977 ; 1981 ; 1987)$ acerca das significações implícitas sinalizadas pelas pressuposições e nas formulações de Grice (1982) acerca do princípio da cooperação, das máximas conversacionais e da geração de implicaturas. Tomando como
\end{abstract}

1 Este artigo se insere no projeto REGE (Reelaborações de gêneros em redes sociais), desenvolvido pelo grupo de pesquisa Hiperged, do Programa de Pós-Graduação em Linguística da UFC

* Universidade Federal do Ceará (UFC).

** Universidade Federal do Ceará (UFC).

*** Universidade Federal do Ceará (UFC). 
categorias de análise as expressões ativadoras de pressuposição e a quebra das máximas, empreendemos a análise de quatro postagens da referida página no intuito de elucidar como se dá a exploração dos implícitos nesse contexto. Os resultados alcançados nos permitem afirmar que os processos inferenciais convocados tanto por pressuposição quanto por implicatura são de fundamental importância para a compreensão dos sentidos do texto, concentrando, por vezes, a principal informação que se deseja comunicar.

Palavras-chave: Pragmática; pressuposição; implicatura.

\begin{abstract}
This article aims to analyze how inferential processing is called to (re)construct meanings in posts from Conselhos do He-Man fanpage on Facebook. To do so, we rely on Ducrot's $(1977 ; 1981 ; 1987)$ reflections on implicit meanings indicated by presuppositions and Grice's (1982) formulations on the cooperation principle, the conversational maxims and implicature generation. As categories of analysis, we chose the expressions that activate presupposition and maxim breaks. Based on that, we conduct an analysis of four posts from the referred fanpage. The goal is to enlighten how the implicit is explored in that context. The results allow us to state that inferential processes called both by presuppositions and by implicature are fundamental to the understanding of text meanings, sometimes condensing the main information which is intended to be communicated to someone.
\end{abstract}

Keywords: Pragmatics; presupposition; implicature.

\title{
1. ConsideraçõES InICIAIS
}

É consensual a ideia de que tanto a leitura quanto a escritura de um texto, seja ele escrito ou oral, passam pelo processamento daquilo que está explícita ou implicitamente posto. Tal processamento, por sua vez, passa necessariamente por aquilo que está circunscrito à língua e pelos aspectos contextuais envolvidos que, no momento da leitura, devem ser inferidos. 
Considerando, então, que na construção de qualquer enunciado estão presentes marcas que orientam a compreensão do(s) sentido(s), neste artigo investigamos algumas postagens da rede social Facebook. Nosso intuito é descrever como as informações implícitas orientam a leitura e a compreensão desse tipo de texto, de modo a gerarem efeitos de sentido que ultrapassam a esfera do que está linguisticamente posto. Assim, inscritos na perspectiva da Pragmática Linguística, ajustamos as lentes ao trato dos fenômenos da pressuposição e da implicatura, os quais pertencem à esfera do não dito ou do não explicitamente dito, com o objetivo de entender como contribuem para a "revelação" das significações suscitadas pelas postagens da fanpage Conselhos do He-Man, ambientada na rede social Facebook ${ }^{2}$.

A distribuição das informações no presente artigo aponta para a seguinte ordem composicional: após esta introdução, apresentamos os conceitos de pressuposição e implicatura, a fim de situá-los no âmbito dos estudos pragmáticos. Em seguida, discorremos acerca da rede social Facebook e da dinâmica que rege as postagens feitas em seu interior; no tópico seguinte, apresentamos o corpus e a metodologia adotados neste estudo; na sequência, procedemos à análise dos dados e, por fim, apresentamos as conclusões alcançadas.

o exercício de análise empreendido revelou aspectos situados na intersecção entre o linguístico e o contextual, mostrando que, por meio das expressões ativadoras de pressuposições e da quebra das máximas conversacionais, a geração de sentidos nas páginas de humor ultrapassa a fronteira do que está dito e convoca significados implícitos. Apesar da relativa complexidade, os seguidores dessas fanpages são capazes de extrair essas informações, estabelecendo uma relação de sentido com o que foi e dito e ainda replicando esses formatos, conforme mostraremos ao longo deste trabalho.

\section{Pressupostos teóricos}

Com o desenvolvimento das reflexões acerca da significação das palavras e das atualizações de sentido provocadas por variações de contexto, emergiram, no cenário da Filosofia da Linguagem, abordagens que iam além

2 Fanpage ou "página de fãs" é um espaço privativo dentro da rede social Facebook que, originalmente, foi destinado a organizações sociais, como produtos, marcas, empresas, instituições. Importantes corporações hoje interagem com seus clientes por meio dessa rede social. Há algum tempo, porém, os usos as fanpage de espraiaram para outros fins, como a criação de páginas de humor, cujos conteúdos giram em torno da publicação de ironias, piadas e indiretas. Uma dessas fanpages é justamente a que analisamos neste artigo: < https://www.facebook.com/CONSELHOSDOHEMAN>. Acesso em 30 out. 2014. 
de uma Semântica Formal, dando origem ao que se convencionou chamar de Virada Pragmática (OLIVEIRA, 2006; LEVINSON, 2007³). Dentro desse contexto, situam-se as reflexões referentes aos implícitos, representados, quase consensualmente, pelos fenômenos da pressuposição e da implicatura, nos quais nos deteremos a seguir.

O fenômeno da pressuposição é, por essência, fluido, e seu trato passa por questões lógico-filosóficas (FREGE, 1978), semântico-pragmáticas (DUCROT, 1977, 1981, 1987) e pragmáticas (AUSTIN, 1990). Ainda que estudado por diferentes vertentes, tal fenômeno tem em Ducrot seu principal expoente, haja vista a dedicação desse teórico para a abordagem da noção de pressuposição. É em função da tentativa de elucidação desse fenômeno linguístico que, no conjunto de sua obra, Ducrot assume diferentes e até mesmo controversas acepções acerca da pressuposição.

Acrescentamos que não pretendemos aqui traçar considerações acerca dessas diferentes visões ducrotianas da pressuposição ${ }^{4}$; nosso estudo encontra-se amparado por Ducrot (1987), para o qual a pressuposição está enquadrada dentro da categoria dos implícitos, os quais podem estar marcados linguisticamente no texto ou não. Focalizaremos, nesta seção, os implícitos que podem ser ativados via processamento linguístico, ou seja, tratemos, a partir de então, dos implícitos pressupostos, conforme Ducrot (1987).

Considerando nossos propósitos, afigura-se relevante que definamos, apoiados em Ducrot (1987), as noções de posto e pressuposto - o conteúdo posto é entendido como as informações que estão contidas no sentido literal das palavras que moldam uma sentença, enquanto o pressuposto é concebido como o conteúdo inferido da enunciação da sentença. Dito de outro modo, podemos entender que o conteúdo posto está na dependência do conteúdo pressuposto, isto é, a aceitação da verdade do posto implica a aceitação da verdade do pressuposto. É por essa razão que, numa sentença como Pedro deixou de fumar, a verdade do posto (Pedro não fuma mais) é aceita somente se a verdade do pressuposto (Pedro fumava antes) também for aceita. Ou seja, para aceitar a informação no nível do posto, é preciso aceitar antes a informação no nível do pressuposto. Todavia, é preciso deixar claro, como bem discute Moura (1999), que o conteúdo pressuposto de uma sentença não é afirmado, mas inferido a partir dela, daí a noção de que a pressuposição passa pela circunscrição da língua e não está literalmente

3 A edição original data de 1983 com o título Pragmatics. Estamos usando a edição brasileira de 2007, traduzida por Luís Carlos Borges e Aníbal Mari e publicada pela editora Martins Fontes.

4 Para um aprofundamento das diferentes visões ducrotianas acerca da pressuposição ver Ducrot $(1977,1981)$. 
marcada na língua. A pressuposição "pertence antes de tudo à frase: (este fenômeno) é transmitido da frase ao enunciado na medida em que deixa entender que estão satisfeitas as condições de emprego da frase da qual é a realização, isto é, o pressuposto está inscrito na língua." (DUCROT, 1987, p. 33).

Vimos discutindo que os pressupostos podem ser ativados e/ou inferidos a partir do sentido literal de palavras ou sentenças, ainda que não estejam contidos aprioristicamente no sentido destas palavras. O que ocorre é que algumas expressões linguísticas, numa dada enunciação, são responsáveis pelo processamento de conteúdos que estão em pressuposição. É bom deixar claro que há, na literatura, várias propostas de agrupamento de expressões linguísticas responsáveis pela ativação de informações pressupostas; mencionaremos aquelas vistas em Moura (1999) e fundadas em Levinson (2007). Temos, portanto, as expressóes definidas, verbos factivos, verbos implicativos, verbos de mudança de estado, os interativos, expressóes temporais e sentenças clivadas, cuja descrição pormenorizada não intentamos. Em nossa análise, não nos pautaremos efetivamente nessa proposta, mas sustentaremos que, nos textos, há conteúdos pressupostos que são ativados via processamento de estruturas linguísticas.

É importante entendermos, conforme assevera Moura (1999), que as pressuposições são sensíveis aos aspectos contextuais, ou seja, elas funcionam dentro de um fluxo conversacional. A função dessas palavras e/ou expressões linguísticas é, dado certo contexto, ativar determinadas pressuposições que fazem parte do conhecimento compartilhado ${ }^{5}$ dos interlocutores. Em outros termos, temos a ideia de que essas pressuposições já estavam lá no grupo de proposições aceitas como verdadeiras por tais interlocutores; as palavras tão somente recuperam essas crenças.

Arroladas essas considerações acerca dos implícitos pressupostos, recorremos, mais uma vez, às palavras de Moura (1999), pelas quais é possível que entendamos que a leitura de um texto passa pelo processamento de inferências corretas e/ou plausíveis que cada texto ou trecho de texto propicia. Passemos, então, ao trato dos implícitos inferidos a partir de aspectos contextuais (pragmáticos): as implicaturas.

No âmbito dos estudos pós-virada pragmática, a relação enunciado/ contexto foi problematizada e parâmetros como as condições de verdade e de felicidade foram abandonados. Em seu lugar, surgiram abordagens que consideravam a dinâmica interacional como principal motivador e orquestrador das manifestações linguísticas; entre elas, podemos citar a teoria da 
polidez (BROWN; LEVINSON, 1987) e a implicatura conversacional (GRICE, 1982), sendo esta última o foco de nossa explanação.

O filósofo inglês e professor da Universidade da Califórnia, Paul Grice, dedicou-se à elaboração de uma teoria capaz de dar conta dos significados adquiridos pelas expressões no momento de sua enunciação, sendo, dessa forma, indissociáveis dos contextos nos quais ocorrem. Para tanto, o autor pressupõe a existência de um princípio geral responsável por gerir as interações conversacionais. Segundo ele (1982, p.68),

nossos diálogos, normalmente, não consistem em uma sucessão de observações desconectadas, e não seria racional se assim fossem. Fundamentalmente, eles são, pelo menos até um certo ponto, esforços cooperativos, e cada participante reconhece neles, em alguma medida, um propósito comum ou um conjunto de propósitos, ou, no mínimo, uma direção mutuamente aceita.

Admitindo a cooperação como elemento pressuposto e, numa perspectiva mais abrangente, constitutivo das conversações, Grice (1982, p. 68) formula o axioma que denominou de princípio da cooperação, o qual estabelece: "faça sua contribuição conversacional tal como é requerida, no momento em que ocorre, pelo propósito ou direção do intercâmbio conversacional em que você está engajado". Dessa forma, esboça um pressuposto geral inerente a toda conversação, capaz de inspirar e elucidar possíveis mudanças de significado motivadas pelo contexto. Ao mesmo tempo, tal pressuposto evita que as expressões linguísticas adquiram fluidez excessiva, o que resultaria em uma semiose infinita e inapreensível.

Para garantir a exequibilidade do princípio da cooperação, Grice (1982) formula ainda um conjunto de máximas conversacionais, postulados gerais subdivididos em pequenas regras que gravitam em torno das interações, no intuito de garantir que a compreensão ocorra. As principais são:

Quadro 1 - Máximas conversacionais segundo Grice (1982)

Máxima da Quantidade, relacionada à quantidade de informação fornecida na conversação:

- Faça com que sua contribuição seja tão informativa quanto necessária para a conversação;

- Não dê mais informações que o necessário. 
Máxima da Qualidade, relacionada à credibilidade das informações fornecidas:

- Não afirme o que você acredita ser falso;

- Não afirme algo para o qual você não possa fornecer evidência adequada.

Máxima da Relevância ou Relação, diz respeito à coerência das informações fornecidas:

- Seja relevante.

Máxima do Modo, cujo objetivo é garantir a clareza daquilo que é enunciado:

- Evite obscuridade de expressão;

- Evite ambiguidade;

- Seja breve (evite prolixidade desnecessária);

- Seja ordenado.

Grice menciona a existência de outras máximas, como a da polidez, mas detêm-se nas quatro principais por julgá-las suficientes para a produção e compreensão das implicaturas conversacionais. Segundo o autor, tanto a observância do princípio da cooperação quanto das máximas seria racional; o primeiro incidiria não apenas sobre a conversação, mas também sobre os comportamentos humanos. Uma vez apreendido esse conjunto de regras, os falantes estariam aptos a decifrar, com a ajuda dos contextos interacionais, tanto as informações ditas quanto as informações comunicadas ${ }^{6}$ nas conversações.

A decodificação das interações com base nas formulações de Grice abrange não só observância e respeito às máximas, mas também o desrespeito a essas regras, gerando o fenômeno chamado pelo autor de implicatura conversacional.

Grice escolhe o verbo "implicitar" (implicate) e suas formas derivadas: implicatura e implicitado, estabelecendo a distinção entre o que se implica e o que se diz. Nessa perspectiva, a mesma elocução pode "sugerir", "indicar", "insinuar" etc coisas diferentes em contextos diferentes. As máximas, uma vez quebradas, convertem-se em caminhos para a constituição de novos significados; o princípio da cooperação converte-se em postulação 
geral que norteia a decodificação desses construtos. Para exemplificar este raciocínio, tomemos a situação dada por Levinson (2007, p. 133):

\section{A: Pode me dizer as horas? \\ B: Bem, o leiteiro já passou.}

No exemplo acima, a máxima da quantidade foi desrespeitada, embora por meio da máxima da relevância seja ainda possível compreender o sentido da resposta dada por B, uma vez que a resposta esperada por A seria a confirmação ou negação da disponibilidade de B em dizer as horas ou, numa perspectiva mais cooperativa, a informação precisa de que horas eram de fato. No entanto, ao responder a pergunta com "Bem, o leiteiro já passou”, B - que, presume-se, respeita o princípio da cooperação - busca, de alguma forma, dar uma contribuição efetiva à conversação, levando-nos a concluir que existe uma relação temporal entre a passagem do leiteiro e a informação requisitada.

A quebra das máximas e a geração de implicaturas ${ }^{7}$, resultantes da construção de sentidos balizada pelos contextos e pelo princípio da cooperação, revelaram-se a principal contribuição de Grice (1982) à Pragmática, pois a sua teoria põe em cena a intrínseca relação que deve existir entre os usos da língua(gem) e seus contextos. Afinal, é possível identificar esse mecanismo em diversas figuras de linguagem, como a metáfora, a metonímia, o eufemismo, a ambiguidade, entre outras.

Devido à relevância para os estudos da significação e à inegável aplicabilidade no que diz respeito às situações conversacionais, a implicatura conversacional configura-se como um mecanismo imprescindível para a boa compreensão dos enunciados. Não se restringindo às interações verbais, mas estando presente também em determinados gêneros escritos inspirados em situações conversacionais, esse fenômeno constitui-se como característica inerente a esses gêneros, demandando dos usuários da língua um desenvolvimento proficiente da capacidade de inferir, embora de uma forma diferente da pressuposição, sob pena de deixarem de apreender determinados sentidos.

A seguir, tratamos da exploração dos implícitos nas postagens propagadas na rede social Facebook. conversacionais generalizadas e particularizadas. 


\subsection{Produção de textos EM Sites de Redes SOciais: AS Postagens do FACEBOOK}

Desde sua criação, em 2004, o Facebook vem se consolidando como site de maior alcance entre aqueles que se propõem a viabilizar a criação e a manutenção de redes sociais digitais. Na perspectiva de Recuero (2009), sites como Facebook, Twitter, Orkut, LinkedIn, entre outros, apenas possibilitam a criação dessas redes, que consistem, por sua vez, nas conexões estabelecidas entre um determinado grupo de atores sociais. $O$ alcance da rede é determinado pelo olhar que se lança sobre ela, podendo abranger desde um grupo pequeno de amigos a um conglomerado de empresas multinacionais.

Uma vez cadastrado no Facebook, o usuário tem a possibilidade de criar um perfil com características identitárias, como descrição pessoal e foto, a partir do qual ele poderá interagir com os demais participantes. A interação nesse ambiente dá-se, geralmente, por meio de postagens escritas, com lugar pré-estabelecido e limite de caracteres ${ }^{8}$. Como instância proponente da conversação, a própria rede procura incentivar as interações em seu interior, apresentando aos usuários a pergunta motivadora "No que você está pensando?", embora os textos compartilhados possuam propósitos e formas bastante diversificados.

Além da conversação entre usuários, o Facebook permite também o acesso e a interação a partir de páginas, denominadas fanpages, arquitetadas em função de um propósito específico, que pode variar de $n$ formas, indo desde motivações institucionais, como a divulgação dos serviços de uma empresa, a motivações lúdicas, como contar piadas. Perfis como esses estabelecem uma interação diferenciada com os demais usuários, fornecendo, geralmente, tópicos conversacionais em torno dos quais girarão novas interações. Para a constituição desses tópicos, as fanpages mobilizam diferentes semioses, como textos escritos, vídeos, imagens ou mesmo a junção desses elementos.

Outra característica inerente aos sites de redes sociais, e bastante utilizada na rede de Mark Zuckerberg ${ }^{9}$, é a possibilidade de replicação dessas postagens, por meio do recurso "compartilhar", que permite ao usuário repassar algo que já foi dito por outra fonte, propagando a informação. Outro importante recurso dessa rede social é o comando "comentar", o qual promove a possibilidade de questionar ou validar esses textos, por vezes multimodais, criando genuínos espaços de interação, como nos mostra a Figura 1, abaixo. 


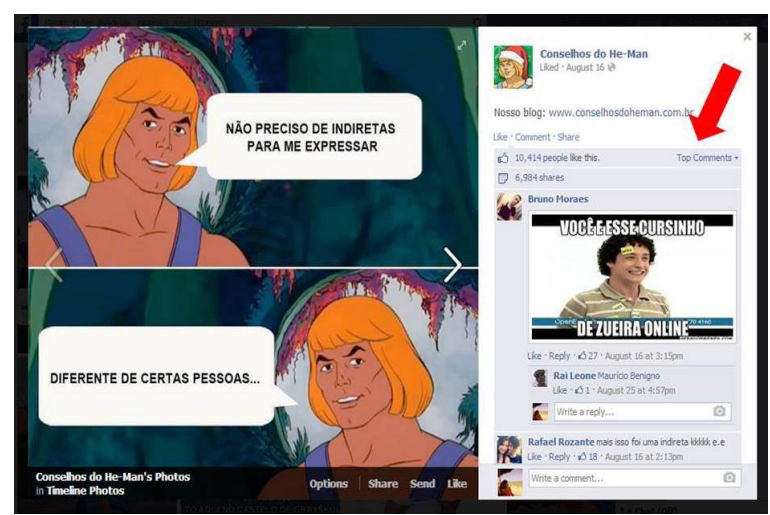

Fig. 1. Aba de comentário

Fonte: <http://goo.gl/ZmNxem>.

Como resultado dessa dinâmica, determinadas postagens podem, eventualmente, atingir elevados níveis de alcance e propagar formatos específicos, inspirando novas versões, adquirindo relativa estabilidade e gerando o que chamamos de même ${ }^{10}$. No caso da Figura 1, por exemplo, podemos observar o registro de 6.984 "compartilhamentos" e 10.414 "curtidas". Esse dado é relevante na medida em que sinaliza para uma das peculiaridades desses textos, que é o amplo alcance que eles possuem na rede social, do qual emerge um encadeamento de pressuposições e implicaturas conversacionais. Dentre esses formatos específicos, identificamos a ocorrência não apenas de efeitos multimodais, mas também de recursos textuais de geração de sentidos, como a ironia, a ambiguidade, a metáfora, entre outros. E, permeando esses enunciados, identificamos a presença constante dos implícitos.

Diante do exposto, no presente trabalho nos propomos a analisar como pressuposição e implicatura conversacional são exploradas nos mêmes, constituindo-se como características inerentes a essa prática discursiva própria das redes sociais e contribuindo de forma imprescindível para a construção de sentidos nesse contexto pragmático. A seguir, apresentamos uma breve descrição dos aspectos metodológicos que nortearam o exercício de análise empreendido.

10 Tributário da noção de gene formulada por Dawkins ([1976] 2001), o conceito de même diz respeito à propagação de ideias, consistindo numa espécie de "gene" da cultura. Segundo Costa (2010, p. 124), "même é ideia, parte de ideia, desenhos, sons ou qualquer coisa capaz de se reproduzir na cultura em unidades autônomas, por meio da imitação. De um ponto de vista evolucionista, são unidades de sentido capazes de sobreviver, em oposição àquelas destinadas ao ostracismo. E como em toda a teoria evolucionista, os mêmes se modificam para sobreviver". 


\section{Aspectos metodológicos}

Para os fins deste estudo, tomamos como locus a rede social Facebook, da qual foram extraídas 10 postagens feitas pela fanpage Conselhos do He-Man. Os dados foram coletados a partir dos perfis pessoais dos pesquisadores, que também são usuários do referido site, e obedeceram aos seguintes critérios de seleção:

i) a presença de expressóes ativadoras ${ }^{11}$, no caso das pressuposições; e

ii) o desrespeito a qualquer uma das máximas conversacionais de Grice, no caso das implicaturas.

A seguir, apresentamos a análise de quatro exemplos ${ }^{12}$ de postagens extraídas do corpus da pesquisa, tomando como categorias a exploração de pressuposições e implicaturas conversacionais.

\section{ANÁlISE DOS DADOS}

Para a compreensão dos enunciados que serão analisados aqui, julgamos necessária uma breve contextualização da fanpage selecionada e a elucidação dos propósitos que permeiam suas postagens.

\subsection{A HistóRIA de He-Man}

Conselhos do He-Man ${ }^{13}$ é uma página do Facebook que tem como proposta propagar textos de tom humorístico-crítico tomando como enunciador o herói protagonista do desenho animado, famoso no final dos anos 80 e início dos anos 90, He-Man. O personagem vive no planeta Eternia, o qual se caracteriza por ser um mundo aparentemente medieval e mágico, mas que se revela cheio de tecnologias avançadas. Eternia é comandado pelo rei Randor e ameaçado corriqueiramente pelo vilão Esqueleto, que tenta dominar o castelo de Grayskull e ter o controle de todo o universo, que é

11 Denominamos aqui de expressões ativadoras aquelas que disparam o gatilho para pressuposições que emergem do princípio de cooperação entre o ator da fanpage e seus seguidores. Essas expressões não possuem uma forma linguística pela qual sejam caracterizadas. $O$ que as define como tal é o seu alcance pragmático gerador de pressuposições entre os atores que põem em cena dizeres irônicos e jocosos.

12 A opção por dois pares de exemplos deu-se no intuito de contemplar de maneira equiparada ambos os fenômenos, flagrando os processos inferenciais sem, contudo, estender-nos demasiadamente, uma vez que os processos ocorrem de forma semelhante nos mais variados contextos.

13 As informações aqui apresentadas podem ser encontradas em

$<$ http://www.mensagenscomamor.com/seriados-filmes-e-novelas/he_man.htm >.Acesso em: 30 out. 2014. 
protegido por He-Man (Adam, o príncipe filho de Randor). Este, ainda jovem, foi contemplado com a dádiva de ser escolhido pela feiticeira Zoar, guardiã do universo e de Eternia, para receber os poderes especiais de uma espada que o transformava em um herói, cujo principal trabalho é proteger o seu reino ao lado de sua guardiã.

Todas as tramas que envolviam o herói He-Man constituem uma série nitidamente direcionada ao público infantil, cujos episódios geralmente encerravam com algum personagem estabelecendo um diálogo com os telespectadores a fim de fazê-los refletir sobre a lição de moral que a história do dia pretendeu transmitir. Expressões como "Na história de hoje..." e "Até a próxima..." eram marcas particulares desses diálogos.

Em se tratando do corpus retirado das postagens da rede social Facebook, mais especificamente, da página intitulada Conselhos do He-Man, é interessante salientarmos que essa, em função de seu propósito de proporcionar humor aos seus seguidores, surgiu a partir de uma tendência, nas redes sociais, de usar personagens e adequá-los às temáticas cotidianas. A ideia, nas palavras dos próprios criadores da página em entrevista ${ }^{14}$ ao site www.bacanudo.com.br, é se valer dos conselhos estranhos que os personagens da série davam no final dos episódios e adequá-los às questões da vida moderna, mas sem que a essência do personagem seja perdida. Para os administradores da página, ela possui identidade própria, ou seja, diferentemente de outras, segue um padrão com "conteúdo diferenciado, bem humorado e sem apelação". Além disso, o personagem He-Man marcou a geração dos anos 80 e 90; ao trazê-lo para as redes sociais, há uma espécie de ressurreição do personagem, dizem os administradores da página.

Considerando essas informações, passemos, então, às análises dos sentidos dos textos selecionados para a composição do nosso exemplário.

\subsection{IMPLÍ́CITOS PRESSUPOSTOS E CONSTRUÇÃO DOS SENTIDOS}

Conforme vimos discutindo, a compreensão de um texto passa necessariamente pelo processamento de informações não ditas ou até mesmo ditas de forma menos explícita, mas que podem ser inferidas a partir de aspectos que particularizam os enunciados. Implicitar informações necessárias à produção e/ou compreensão dos sentidos é uma ação que se manifesta, em nosso corpus, como um investimento discursivo dos autores da fanpage 
para particularizar as postagens que analisamos neste trabalho. Para que essa estratégia discursiva seja vislumbrada, vejamos, na Figura 2, como as informações não ditas explicitamente podem ser ativadas, via marcas linguísticas, de modo a cumprir o propósito desse tipo de texto.

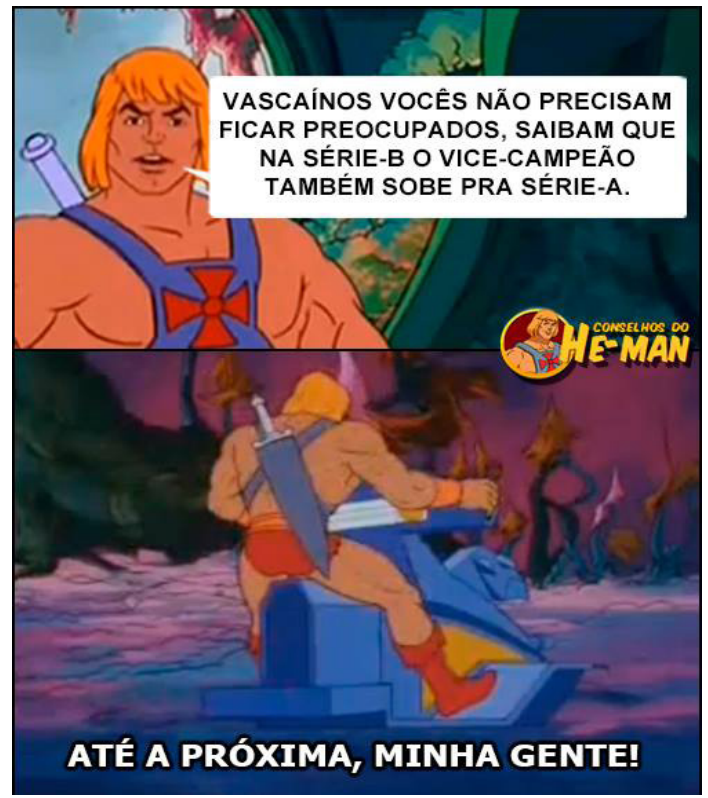

Fig. 2. Exploração de pressuposição 1

Fonte: <http://goo.gl/ljDuu9>.

Nesse exemplo, antes de tudo, é preciso que se assuma que o termo "Vascaínos" faz referência a um ser específico no mundo, acionando, assim, o pressuposto da existência e mantendo uma relação de equivalência com a expressão definida "o vice-campeão". A pressuposição está na existência de cada um desses seres. Temos, ainda, na construção desse enunciado, a expressão verbal "ficar preocupados", que, funcionando em subordinação à estrutura oracional "Vascaínos vocês não precisam", carrega o pressuposto de que "Vascaínos são/estão preocupados", que é considerado como sendo de conhecimento de locutor e dos interlocutores do texto. Dessa maneira, reiteramos que, para que haja aceitação do conteúdo posto em um texto, é preciso que se considere como verdade o conteúdo pressuposto. Há, no texto, várias outras inferências que devem ser ativadas para que haja uma construção de sentidos plausível, como por exemplo, "Vascaínos estão na série B", "Vascaínos podem subir para a série A". Entretanto, consideramos que todas as inferências que podem ser feitas pelos interlocutores desse texto 
passam pela aceitação da informação de que "O Vasco da Gama carrega a fama de ser vice-campeão em campeonatos", a qual orienta a construção dos sentidos e do humor nesse texto.

Vejamos este outro exemplo na figura subsequente.

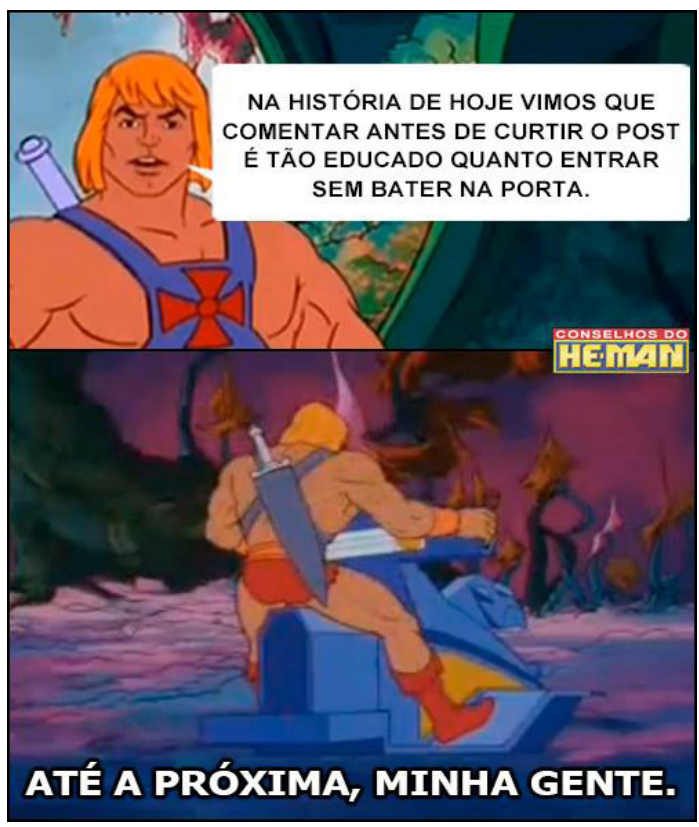

Fig. 3. Exploração de pressuposição 2

Fonte: <http://goo.gl/yLjiSz>.

O tom humorístico desse texto é construído com base nas informações relativas à boa educação, seja ela em ambientes reais ou virtuais. Temos, nesse sentido, a ideia de que "Invadir não é educado". Essa informação é, de modo geral, inferida do texto e posta em equiparidade aos comportamentos em redes sociais. Tal relação é promovida pela expressão de igualdade "tão...quanto". É interessante que se entenda que essa relação só pode ser estabelecida se as inferências "Pessoas comentam posts antes de curtir" e "Pessoas entram em ambientes antes de bater" forem aceitas como "quebra de regras de comportamento". Pode ser dito, ainda, que essa noção de "quebra de regras de comportamento" (sendo essas regras parte do conhecimento compartilhado dos interlocutores) pode ser construída se considerarmos o localizador temporal "antes de", o qual nos permite pressupor que "Pessoas curtem" e "Pessoas batem". Diante disso, ressaltamos, mais uma vez, que essas expressões motivadoras disparam o gatilho para 
que essas marcas linguísticas revelem informações implícitas necessárias à construção dos sentidos dos textos aqui em questão.

\subsection{Quebra dE MÁXIMAS, IMPLICATURAS E GERAÇÃo DE SENTIDOS}

Nos exemplos selecionados, a quebra ostensiva das máximas conversacionais formuladas por Grice (1982) foi bastante produtiva e, por vezes, crucial para a geração de implicaturas que orientavam a intenção do autor no que diz respeito à compreensão esperada para o texto postado. Vamos aos exemplos:

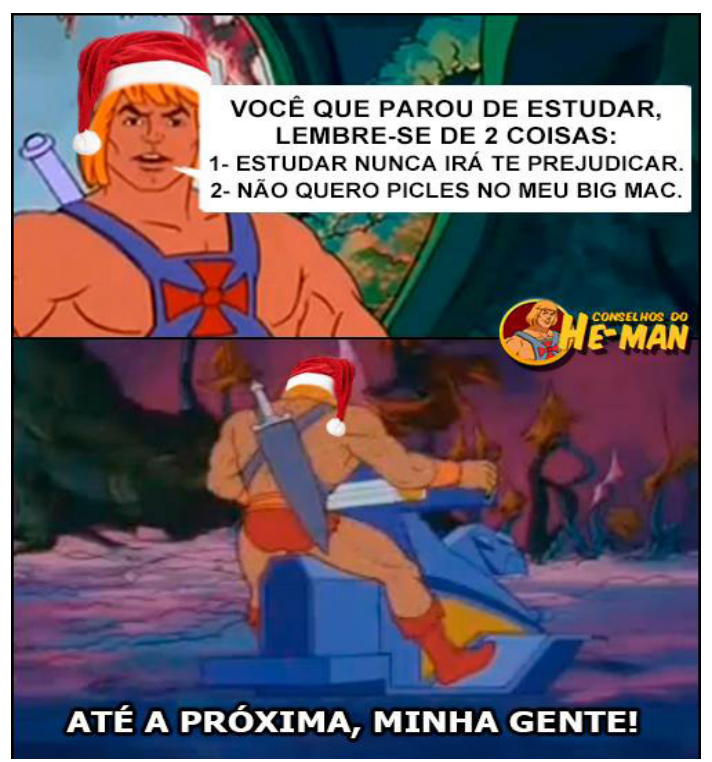

Fig. 4. Quebra da máxima da relevância e geração de implicatura Fonte: <http://goo.gl/20soof $>$.

$\mathrm{Na}$ Figura 4, algumas expressões motivadoras entram na composição do texto e disparam o gatilho para que o leitor perceba que a sequência das proposições "estudar nunca irá te prejudicar" e "não quero picles no meu big mac" leva o personagem He-Man a violar a máxima da relevância, apresentando enunciados que, a princípio, parecem desconexos. Contudo, para extrair o sentido imbricado nessa relação, é necessário observarmos o princípio da cooperação, a partir do qual inferimos que o enunciador quis, apesar da violação da máxima, fazer sua contribuição de maneira adequada. De posse disso, voltamos ao texto em busca de hipóteses que conectem as 
proposições numa relação de sentido aceitável. Dessa forma, buscamos contextos nos quais tanto a proposição 1 quanto a proposição 2 relacionem-se ao contexto "parar de estudar". Tomando com pista a segunda proposição, inferimos que a frase imperativa em questão é produtiva numa situação na qual alguém, provavelmente o destinatário da mensagem, deixou de estudar. Considerando ainda que "big mac" é o nome de um sanduíche fabricado e vendido por uma famosa rede de fast food, somos levados a concluir que deixar de estudar pode levar alguém a este lugar, e a fala imperativa demarca a posição de subordinado ocupada por esta pessoa. Assim, chega-se, finalmente, à relação entre a proposição 2 e o enunciado que antecede a enumeração (você que parou de estudar, lembre-se de duas coisas). Feito este percurso, podemos afirmar que, para além do que está dito no texto, o enunciador implicita ainda que a rede McDonalds é um lugar no qual trabalham pessoas com baixo grau de escolaridade e apenas com a decodificação dessa informação é possível compreender o sentido do texto.

Sigamos o exercício analítico examinando o próximo exemplo:

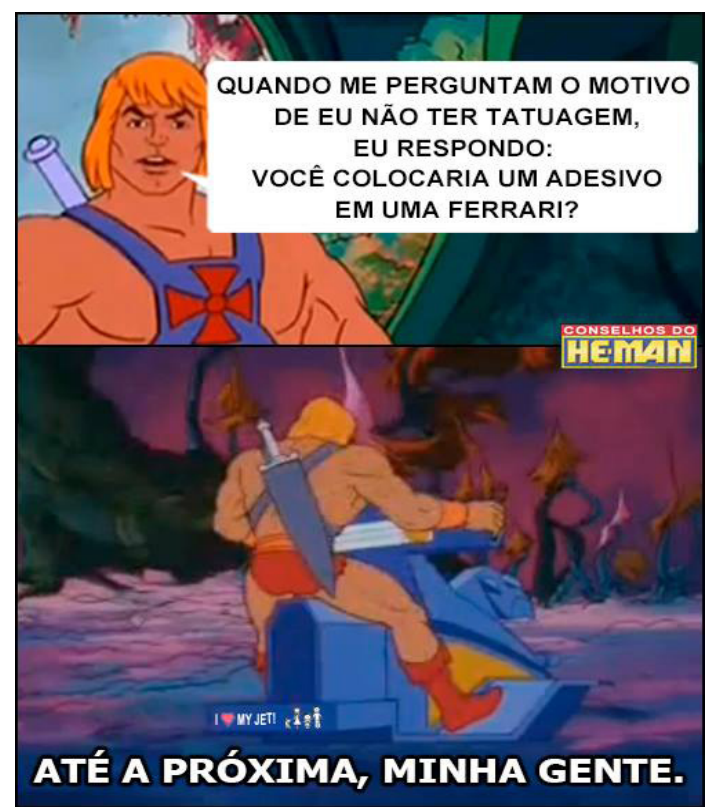

Fig.. 5. Quebra das máximas de quantidade e de relevância e geração de implicatura Fonte: <http://goo.gl/qI39yE >. 
No exemplo acima, temos o relato de um caso de violação de duas máximas, ao vermos uma pergunta ser fornecida como resposta a uma outra questão. As violações, nesse caso, dizem respeito à quantidade de informação fornecida e à relevância do que é dito. As expressões ativadoras desse exemplo mostram que, ao construir sua resposta com a proposição "você colocaria um adesivo numa Ferrari?", o personagem He-Man nos leva a procurar contextos nos quais uma pergunta pode ser aceita como resposta a uma outra questão. E ainda, em que aspecto o fato de colocar-se um adesivo numa Ferrari pode relacionar-se à aquisição de uma tatuagem. Em busca desse percurso de significados, somos levados a admitir a aproximação, via metáfora, entre o carro mencionado e o corpo do personagem. Tal aproximação, acrescida do conhecimento de mundo do valor associado à marca Ferrari nos leva a inferir, via implicatura conversacional, que o personagem considera seu corpo um bem de elevado valor, revelando assim, propositalmente, um aspecto narcisista de sua personalidade.

A análise nos permite arrazoar que a interação entre os usuários da fanpage "Conselho de He-Man" se dá prioritariamente não apenas em função dos textos postados, mas também pela capacidade de seus seguidores de mobilizarem recursos pragmáticos de construção de sentido. É em função da conexão desses aspectos que podemos compreender a importância dessas unidades de significação na manutenção da dinâmica de interação desse tipo de página em redes sociais. Nesse sentido, a capacidade de reconstruir sentidos acionados por pressuposições e implicaturas revela-se fundamental para os usuários do Facebook que interagem com esse tipo de página de humor.

No que diz respeito à prática de construção de sentido e interação com o texto, esse estudo corrobora a tese de que o processo de construção de sentido "não se dá linearmente, de maneira cumulativa, em que a soma do significado das palavras constituiria o significado do texto" (TERZI, 2002, p. 15). Pelo contrário, ler é uma atividade complexa e exige a mobilização de múltiplos processos cognitivos e pragmáticos sem os quais não acessaremos os significados que emergem da interação que podemos estabelecer com o texto. Rastrear, por exemplo, as expressões motivadoras de pressuposições em textos como os que analisamos neste artigo é aceitar que todo "texto tem um potencial de evocar significado, mas não tem significado em si mesmo" (MOOR et al., 2001, p. 160). Desse modo, ao estudarmos o processamento inferencial nas postagens da fanpage "Conselhos do He-Man", notamos que os processos inferenciais são fulcrais para a geração e apreensão dos sentidos almejados pelo enunciador das postagens analisadas, pois, seja via pressuposição, seja via implicatura, há sempre algo além daquilo que está formalmente dito. 


\section{E NA HISTÓRIA DE HOJE VIMOS QUE...}

Ao final de nosso percurso, podemos concluir, com base nos dados analisados, que, no que diz respeito aos textos escritos produzidos no âmbito das postagens da rede social Facebook, a exploração dos processos inferenciais é constante e de fundamental importância para a construção dos sentidos dessas interações. Observamos a mescla de aspectos contextuais e linguísticos contribuindo para a (re)construção de sentidos por meio de conteúdos pressupostos, convocados por expressões ativadoras produtivamente exploradas pelos enunciadores. Ademais, também foi possível flagrar a contribuição dada aos sentidos por meio da concatenação de aspectos contextuais e cognitivos, materializados na quebra das máximas conversacionais e tendo como resultado a criação de implicaturas, que são prontamente decodificadas pelos usuários, conforme evidenciam os índices de comentários e compartilhamentos atingidos por esses textos. Diante desses resultados, podemos inferir que, para participar de maneira proveitosa dos sites de redes sociais e estabelecer interações a partir das postagens de uma fanpage humorística, é interessante que os usuários tenham desenvolvidas as habilidades de identificar pressuposições e implicaturas, tornando-se, dessa forma, proficientes no processo de (re)construção de sentidos, empreendido em cooperação com o autor do texto.

Possíveis questionamentos que emergem dessa reflexão são: a que altura do processo de aquisição da leitura/escrita, o indivíduo desenvolve essa habilidade de identificar e decodificar pressuposições e implicaturas? A interação em redes sociais apenas favorece essa habilidade ou pode também criá-la? Há interações que não obedeçam a esse padrão? São questões que podem ser abordadas em pesquisas futuras.

No que diz respeito às aplicações desse resultado, julgamos promissoras abordagens que promovam o exercício de reconhecimento e (re) construção de sentidos implícitos como etapa do processo de aquisição da leitura/escrita. Para além da compreensão, vemos nos mêmes um modelo relativamente estável de texto que pode ser usado como motivador para produção textual com foco na exploração dos processos inferenciais, induzindo os alunos a irem além do dito e assenhorando-se também daquilo que, como disse Grice (1982), é comunicado. 


\section{REFERÊNCIAS}

AUSTIN, John Langshaw. Quando dizer é fazer. Tradução de Danilo Marcondes de Souza Filho. Porto Alegre: Artes Médicas, 1990.

BROWN, Penelope; LEVINSON, Stephen. Politeness: some universals in language usage. Cambridge: University Press, 1987.

COSTA, Rafael Rodrigues da. A TV na Web: percurso da reelaboração de gêneros audiovisuais na era da transmídia. 2010. 173 f. Dissertação (Mestrado em Linguística) - Programa de Pós-Graduação em Linguística da Universidade Federal do Ceará, Fortaleza, 2010.

DAWKINS, Richard. O Gene Egoísta (1979). Belo Horizonte: Itatiaia, 2001.

DUCROT, Oswald. Princípios de semântica linguística: dizer e não dizer. Tradução de Carlos Vogt, Rodolfo Ilari e Rosa A. Figueira. São Paulo: Cultrix, 1977.

. Provar e dizer: leis lógicas e leis argumentativas. Tradução de Maria Aparecida Barbosa, Maria de Fátima Gonçalves Moreira e Cidmar Teodoro. São Paulo: Global, 1981.

. O dizer e o dito. Tradução revisada de Eduardo Guimarães. Campinas, SP: Pontes, 1987.

FREGE, Gottlob. Sobre o sentido e a referência. Tradução de Paulo Alcoforado. In: Lógica e filosofia da linguagem. São Paulo: Cultrix, 1978.

GRICE, Herbert Paul. Lógica e conversação. In: DASCAL, M. Fundamentos Metodológicos da Linguística: Pragmática. Vl. IV. Campinas: IEL/Unicamp, 1982, p.81-103.

LEVINSON, Stephen. A implicatura conversacional. In: Pragmática. São Paulo: Martins Fontes, 2007a. p.121-163.

. A pressuposição. In: Pragmática. São Paulo: Martins Fontes, 2007b. p. 209-286.

MOOR, Anne Marie et al. O ensino colaborativo na formação do professor de inglês instrumental. In: LEFFA, Vilson. (Org.). o professor de línguas estrangeiras: construindo a profissão. Pelotas: Educat, 2001. p. 157-173.

MOURA, Heronides Marílio de Melo. Pressuposição. In: Significação e Contexto: uma introdução a questões de Semântica e Pragmática. Florianópolis: Insular, 1999.

OLIVEIRA, Manfredo Araújo de. Reviravolta Linguístico-Pragmática na Filosofia Contemporânea. São Paulo: Edições Loyola, 2006.

RECUERO, Raquel. Redes sociais na Internet. Porto Alegre: Sulina, 2009.

TERZI, Sylvia Bueno. A construção da leitura. 3. ed. Campinas: Pontes, 2002.

Submetido em: 09/03/2014

Aceito em: 17/10/2014 